of about the same quantity, after which complete analytical data and a detailed account of the preparation will be published elsewhere.

When the composition and properties of the amino acid are definitely established, it will be necessary to show that it is really a primary component of protein. It is possible that the sulphur has been introduced into the molecule either from the sulphuric acid used in hydrolysis, or from the $\mathrm{H}_{2} \mathrm{~S}$ used throughout the preparation. The possibility of introducing sulphur from sulphuric acid is rather remote, since the amino acid has not the properties of a sulphonic acid. However, it can be excluded only by the use of enzyme digestion or alkali hydrolysis in the primary breaking down of the protein, and this has not yet been attempted. In the preparation as outlined above, it is apparently not possible to avoid the use of $\mathrm{H}_{2} \mathrm{~S}$, and this factor can be ruled out only by the elaboration of a method based on quite different principles, or by careful quantitative determinations of total sulphur throughout the various fractions, which is not likely to prove very satisfactory. It is not apparent, however, just how sulphur from $\mathrm{H}_{2} \mathrm{~S}$ could be introduced into any of the known amino acids to give a compound of the above formula.

Should it be possible to exclude these sources of extraneous sulphur, this compound will probably account for a part at least of the non lead-blackening sulphur known to be present in certain proteins. The amount present may well be considerably in excess of the present yield, since the method is obviously not quan titative.

$$
76 \text { (1823) }
$$

The inheritance of susceptibility to implants of splenic tissue in mice.

1. Japanese waltzing mice, albinos, and their $F_{1}$ generation hybrids.

By C. C. LITTLE and B. W. JOHNSON.

[From the Carnegie Institution of Washington, Cold Spring Harbor, N. Y.]

The use of the terms "auto," "homio," and "hetero" transplantation has been general and of great value in the long series 
of experiments which have dealt with the transplantation of normal and of neoplastic tissues in vertebrates.

Following a number of experiments in this field, covering a wide range of material, it has become generally recognized by biological investigators that the closer the genetic relationship between the host and the donor of the graft tissue, the greater is the likeliho'd of persistent and progressive growth of an implant of tissue from one to the other.

Similarly it has been found that in the ordinary "laboratory" races of mammals, inbreeding has not been intensive enough to have produced a close degree of genetic resemblance between individuals within the race. Without this resemblance the continued growth of tissue transplants made from one animal to another is impossible. When close relatives such as parent and offspring or litter mates are picked for this interchange of implants, there is, as Loeb and others have pointed out, more chance of persistence of the implants than when unrelated animals are used. Loeb ${ }^{1}$ has proposed the term "syngenesio-plastic transplantation" for experiments involving the close relatives referred to.

When, however, closely inbred races of known genetic constitution are used, results are obtained which show that the distinctions between "homio," "syngenesio," and "auto" transplantations are only relative and may be deliberately broken down by picking animals of certain definite genetic constitutions for experimentation.

Thus in animals of a closely inbred and genetically homogeneous strain of Japanese waltzing mice [already described in connection with experiments on the inheritance of susceptibility to transplanted tumors ${ }^{2}$, the general reactions of an individual to subcutaneous transplants of bits of its own spleen (autotransplants), or to bits of the spleen of another Japanese waltzing mouse of the same inbred race (homiotransplants) were the same. Both implants "auto" and "homio" persisted successfully, established a blood supply, and remained healthy.

${ }^{1}$ Loeb, L.eo, Journ. Med. Research, 1918, xxxix, 39-57.

${ }^{2}$ Little, C. C., and Tyzzer, E. E., Journ. Med. Research, 1916, xxxiii, 393-453. 
TABLE I.

\begin{tabular}{|c|c|c|c|c|c|}
\hline \multirow{2}{*}{ Cross No. } & \multirow{2}{*}{ Races. } & \multicolumn{2}{|c|}{$\begin{array}{l}\text { Autotrans- } \\
\text { plants. }\end{array}$} & \multicolumn{2}{|c|}{$\begin{array}{l}\text { Homiotrans- } \\
\text { plants. }\end{array}$} \\
\hline & & + & - & + & - \\
\hline $\mathbf{I}$ & Japanese waltzing $\times$ Japanese waltzing & 22 & $\mathrm{I} * a$ & 22 & $\mathbf{I} * a$ \\
\hline 2 & $\begin{array}{l}\text { Japanese waltzing } \\
\times \text { albino }\end{array}$ & $\begin{array}{l}14 \\
16\end{array}$ & $\begin{array}{l}\mathrm{I} * b \\
\mathrm{I}_{c}\end{array}$ & $\begin{array}{l}0 \\
0\end{array}$ & $\begin{array}{l}15 * b \\
17 * c\end{array}$ \\
\hline 3 & $\begin{array}{l}\text { Japanese waltzing } \\
\times F_{1} \text { hydrids }\end{array}$ & $\begin{array}{l}23 \\
33\end{array}$ & $\begin{array}{l}0 \\
0\end{array}$ & $\begin{array}{r}0 \\
33\end{array}$ & $\begin{array}{r}23 \\
0\end{array}$ \\
\hline
\end{tabular}

+ means persistence of the implant in a healthy condition.

- means disintegration of the implant.

*a-Mouse sick and probably unable to provide adequate nourishment for either implant.

*b-One mouse negative to both auto and homio, probably due to poor operative technique or to mouse being in poor physical condition.

${ }^{*} c$-One mouse negative to both auto and homio, probably due to poor operative technique or to mouse being in poor physical condition.

These results are tabulated in the top two lines of Table I. It should be noted that in one animal neither the autotransplant nor the homiotransplant persisted. Records show that this animal was in markedly poor physical condition and this without doubt accounts for the elimination of both implants.

When interchange of splenic implants was made between Japanese waltzing mice and unrelated albino non-waltzers, the results shown in lines 3 and 4 of Table I were obtained.

One Japanese waltzing mouse and one albino failed to support either the auto or the homio implant. This was probably due to poor technique involving infection after the operation. If these animals are subtracted from the totals we find that the autotransplants in either the Japanese waltzers or the albinos are successful, while the homiotransplants from albino to waltzer or vice versa are uniformly unsuccessful.

This, it will be remembered, is the result ordinarily obtained in homiotransplantation and adds another piece of evidence to our belief that similarity in genetic constitution is essential for successful implantation of splenic tiss ue.

The interesting and crucial test of the correctness of the hypothesis on which the experiments were planned is found in the 
case of reciprocal transplants between Japanese waltzers and $F_{1}$ generation hybrids, formed by crossing together the waltzers and the albinos.

In this case, analogy with the tumor work and knowledge of the genetic constitution of the animals lead us to suspect that implants of waltzing mouse spleen should grow in the $F_{1}$ hybrids, while implants of splenic tissue from the hybrids should not persist in the waltzing mice. This was actually found to be the case, as can be seen from the two bottom lines of Table I.

The gametes of the Japanese mice were, by hypothesis, essentially equal in respect to their genetic factors. Each $F_{1}$ hybrid had therefore received from its waltzing mouse parent approximately the same genetic contribution. This was of such a nature as to make possible the persistence of implants coming from the Japanese mouse. (The same was found to hold true in the case of tumors of the Japanese mouse.)

The $F_{1}$ tissue which was implanted in the Japanese waltzers comes from animals approximately half of whose genetic constitution is determined by their albino parent. Since the Japanese mice had not the genetic factors which made up the albino complex, we should not expect that they could support the hybrid implants.

The results, therefore, in all three series are in complete harmony with the hypothesis advanced by Little and Tyzzer (1916), namely: that the susceptibility of any mouse to implants of foreign tumor tissue depends upon the genetic constitution of the host in its relation to the genetic constitution of the animal from which the implant was taken.

The value of the term "syngenesiotransplantation" seems to be greatly impaired for:

(a) Parents (waltzers) failed uniformly to support implants of the splenic tissue of their progeny.

(b) Progeny ( $F_{\perp}$ hybrids) grew regularly the splenic tissue of their parents.

There is in this case an absolute difference in the results obtained, depending upon which race is used as the host. The fact that the "genetic" relationship changes while the "pedigree" relationship remains the same, shows that the former is the important factor in determining the nature of the result. 
The evidence obtained from the Japanese waltzing mice shows that within a closely inbred race, homiotransplants of splenic tissue may be quite as successful as autotransplants.

The experiments further show that in all probability susceptibility to transplants of splenic tissue depends upon the same general principles of heredity found to apply in the case of tumor tissuenamely, multiple mendelizing factors.

$$
77 \text { (1824) }
$$

\section{Observations on cod-liver oil and rickets.}

By T. F. ZUCKER, A. M. PAPPENHEIMER, and MARION BARNETT.

[From the Department of Pathology, College of Physicians and Surgeons, Columbia University, New York City.]

In view of the nearly specific action that cod-liver oil has on rickets, it is of interest to inquire into the nature of the substance conferring on it the therapeutic properties. Several attempts have been made to isolate from it materials that could be made responsible for its action. Gautier and Morgues ${ }^{1}$ isolated the organic bases contained in the oil and separated from them two alkaloid-like substances besides the simpler aliphatic amines. Funk $^{2}$ also worked with this mixture of bases which he fractionated in various ways. None of these observers, however, have published any data on the action of the isolated material. Stöltzner ${ }^{3}$ claims, without giving any details of his evidence, except the statement that he cured even the worst cases of rickets, that hydroxy acids confer upon cod-liver oil its pharmacological properties. Freudenberg and Klocmann ${ }^{4}$ had expressed similar ideas and prepared calcium salts of the unsaturated acids of cod-liver oil which they used in the treatment of spasmophilia.

Wacker and Beck ${ }^{b}$ believe that "besides other chemically not yet well characterized substances, cholesterol plays a significant rôle in the antirachitic fat soluble factor A."

1 Gautier and Morgues, C. R. Acad. Sci., 1888, cvii, I10 and 626.

2 Funk, Biochem. Bull., 1915, iv, 365.

- Stöltzner, Münch. med. Wochenschr., I921, lxviii, 272.

- Freudenberg and Klocmann, Jahresb. f. Kinderh., I913, lxxviii, 47; 1914, xxix, 700.

- Wacker and Beck, Berl. klin. Wochenschr., 1921, 1xxxv, 453. 